\title{
Mushrooming Higher Education Institutions: Quality of Education and Employability
}

\author{
Ekta Sharma* \\ Associate Professor, Ahmedabad University, India
}

Submission: December 13, 2018; Published: March 07, 2019

"Corresponding author: Ekta Sharma, Associate Professor, Amrut Mody School Of Management, Ahmedabad University, Gujarat, India

\section{Opinion}

"The great aim of education is not knowledge but action"

\section{-Herbert Spencer.}

Education is vital to development, empowerment and strengthening of the country and its citizens. It is one of the most powerful weapons to fight the evils of widespread poverty and inequality and thereby ushering a path to sustained economic growth. The world is witnessing the rapid expansion and diversification of Higher Education sector owing to academic, political, and commercial developments associated with globalization, such as the rise of market forces in Higher education sector and the umpteen opportunities for the skilled professionals and graduates. The privatization of higher education has increased the enrollments in the Higher educational Institutions (HEI), thereby increasing the flux of the graduates in the labour market. But the irony is that not all graduates are employable.

The data is evident that the 14 percent of the graduates and 12 percent Post graduates in India are unemployed. Such transformations have, therefore, raised question about the Quality of higher education. Although the quality of HEIs was indubitable when they had fewer students and the fewer institutions but with the increase in HEI's and the enrolling students, questions about quality of education and graduate employability are the pop-ups, seeking clarification. This brings academic quality of HEIs under scrutiny and hence the policy makers have recommended external as well as internal quality assurance systems in HEI's. The external quality assurance systems are managed through accreditations by different bodies like National Assessment and Accreditation Council (NAAC). But the Internal quality Assurance cell (IQAC) has a bigger responsibility to monitor and manage quality of higher education. The IQAC needs to redefine and realign teaching and learning to cater to the demands of the employment/labour market and to achieve this the key factors would be the leadership support, stakeholder involvement, strategic alignment of IQAC and an effective management information system.

All institutions are expected to have quality assurance mechanisms in place as a way of assuring stakeholders about the high standards of their programmers and their achievement through outcomes. The key aim of quality assurance is to monitor performance as well as to ensure the achievement of quality outputs. To achieve this, the IQAC should seek suggestions and feedback from all its stakeholders, primarily, Student, Teacher and Recruiter and should revise the curriculum regularly based on these suggestions. The nature of jobs is changing rapidly and regularly, making few jobs and skills obsolete and rendering the graduate unemployed.

The HEIs need to address the issue of skill obsolescence, in order to arrest unemployability. One of the key contributions of HEI's to develop employable graduates could be to not only provide knowledge and skills but also to develop the right attitude to learn, adapt and grow. Having the right attitude would prepare a graduate to not only survive in the current situation but also find the way in the future, thereby leading to the sustainable growth of an individual. Employers want graduates who can quickly adapt to the workplace culture, who can use their abilities and skills to evolve an organization and can use higher-level skills to facilitate innovative teamwork. 
- Quality Editorial service

- Swift Peer Review

- Reprints availability

- E-prints Service

- Manuscript Podcast for convenient understanding

- Global attainment for your research

- Manuscript accessibility in different formats

( Pdf, E-pub, Full Text, Audio)

- Unceasing customer service

Track the below URL for one-step submission https://juniperpublishers.com/online-submission.php 